\title{
The Economic Impacts of Restrictions on the Transportation of Petroleum Coke
}

\author{
Timothy J. Considine \\ Department of Economics and Finance, University of Wyoming, Laramie, WY, USA \\ Email: tconsidi@uwyo.edu
}

How to cite this paper: Considine, T.J. (2019) The Economic Impacts of Restrictions on the Transportation of Petroleum Coke. Natural Resources, 10, 59-80. https://doi.org/10.4236/nr.2019.103005

Received: February 15, 2019

Accepted: March 24, 2019

Published: March 27, 2019

Copyright $\odot 2019$ by author(s) and Scientific Research Publishing Inc. This work is licensed under the Creative Commons Attribution International License (CC BY 4.0).

http://creativecommons.org/licenses/by/4.0/

\begin{abstract}
Petroleum coke is the third leading refined petroleum product export from the US behind distillate fuel oil. Legal challenges and proposals could either increase the cost or restrict the transportation of petroleum coke. This paper develops an econometric model of world markets for refined petroleum markets to estimate the effects of such restrictions. The model is used to estimate how supply, demand, trade flows, and prices would adjust under a shutdown of US petroleum coke production. The market impacts are significant, with substantially higher prices for jet fuel and petroleum coke, significantly higher prices for gasoline and other products, and sharply lower prices for residual fuel oil. Over a four-year simulation of the model, the US petroleum trade balance deteriorates by $\$ 85$ billion and consumers pay over $\$ 187$ and $\$ 376$ billion more for refined petroleum products in the US and the rest of the world respectively.
\end{abstract}

\section{Keywords}

Petroleum Coke, Transportation, Petroleum Product Prices

\section{Introduction}

The United States is the world's largest producer of petroleum coke, producing almost half of world production from processing units, known as "cokers" that also produce significant amounts of feedstocks for other refined petroleum products as noted by Leffler [1]. The economic driver to build coking units is to increase the yield of transportation fuels from a refinery. Coker capacity has been rising in the US since 1990 in part by taking advantage of low cost, heavy, high sulfur bitumen from Canada. This petroleum coke is shipped to nearby port facilities where it is temporarily stored for subsequent transportation to domestic and international markets. 
Local neighborhood organizations in Detroit and Chicago have complained about the dust created from piles of coke stored along public waterways, see Muller [2]. Senator Durbin [3] from Illinois proposed an amendment to the Keystone XL Pipeline bill in the US Senate that would have regulated petroleum coke as a hazardous waste. National environmental groups, such as the Natural Resources Defense Council [4] and Oil Change International [5], have also raised the issue of greenhouse gas emissions associated with the use of petroleum coke. As a result, Jordon [6] proposed a ban on petroleum coke in Chicago and Upton [7] reported that San Francisco also considered a ban on the export of petroleum coke. If enacted, these policies would restrict transportation of petroleum coke and could affect markets for refined petroleum products. The objective of this study is to determine the economic impacts of restrictions on the transportation of petroleum coke.

To estimate this value, this study specifies and estimates an annual econometric model of world markets for refined petroleum products. The model has two regions-the United States and the rest of the world-and seven product categories including gasoline, distillate fuel oil, jet fuel and kerosene, residual fuel oil, liquid petroleum gases, petroleum coke, and other petroleum products, such as waxes, naphtha, and asphalt. Econometric models for the demand and supply for each of these products in the two regions are estimated. Combined with market clearing identities, the supply and demand relations for each of the seven product markets in the two regions are used to solve for equilibrium prices so that excess demand in one region is balanced by excess supply in the other. This approach allows a simple framework for modeling how supply and demand shocks affect prices for refined petroleum products and net trade flows.

The next section of this paper explains the nature of petroleum coke and its role in modern refineries. Section two discusses the specification of the demand and supply models. The paper then provides an overview of trends in world production and consumption of petroleum coke and other refined products. The econometric estimates of the supply and demand elasticities are presented in the fourth part of the paper. In section five, a dynamic simulation of this model is used to develop a base case to compare with a scenario that phases out petroleum coke production in the US. Changes in equilibrium prices between these two scenarios provide a basis for estimating the value of petroleum coke capacity. The paper concludes with a summary of the main findings.

\section{Petroleum Coke Production and Use}

Petroleum refineries convert crude oil and natural gas liquids into refined petroleum products. Like crude oil, these products fall into two broad categories: light and heavy. Over time, refiners adjust and optimize their technology based upon the availability and price of various types of crude oil, changing consumer preferences, and environmental regulations. One challenge for refiners is meeting increasing demand for light petroleum products while adjusting to declining 
demand for residual fuel oil. As refiners increase their crude distillation runs to meet rising demand for gasoline and other light petroleum products, they produce large volumes of residues that when blended or "cut" with lighter products can be sold as residual fuel oil. The market for these residual fuels, however, has been shrinking over time and other heavy petroleum products, like asphalt, have limited markets. Hence, the logical decision is to convert these residues into light products using petroleum cokers. As a result, residual fuel oil consumption as a percentage of the total weight of world oil consumption has been steadily declining over the past 40 years while the corresponding percentage for petroleum coke has been increasing (see Figure 1). Residual fuel oil comprised 35\% of world oil consumption in 1974 and decreased to $11 \%$ in 2012. In contrast, the percentage by weight of petroleum coke in world oil consumption more than doubled over the period from less than $1 \%$ in 1974 to $2.6 \%$ in 2012 .

The relationship between petroleum coke, residual fuel oil, and light product production for the United States is illustrated in Figure 2. Light petroleum production, which includes gasoline, distillate fuel, aviation fuels, liquid petroleum gases, and blending components including oxygenates, such as ethanol, increased from 12 million barrels per day (mmbd) in 1983 to over $17 \mathrm{mmbd}$ in 2012. Over the same time period, residual fuel production fell $50 \%$ to just below 500 thousand barrels per day. In contrast, US petroleum coke production more than doubled to over 850 thousand barrels per day.

Coker throughput and the contribution of cokers to light product production is illustrated in Figure 3. From 1993 to 2013, inputs to cokers increased from 1.5 to $2.3 \mathrm{mmbd}$ (see Figure 3). Meanwhile, petroleum coke output increased 250

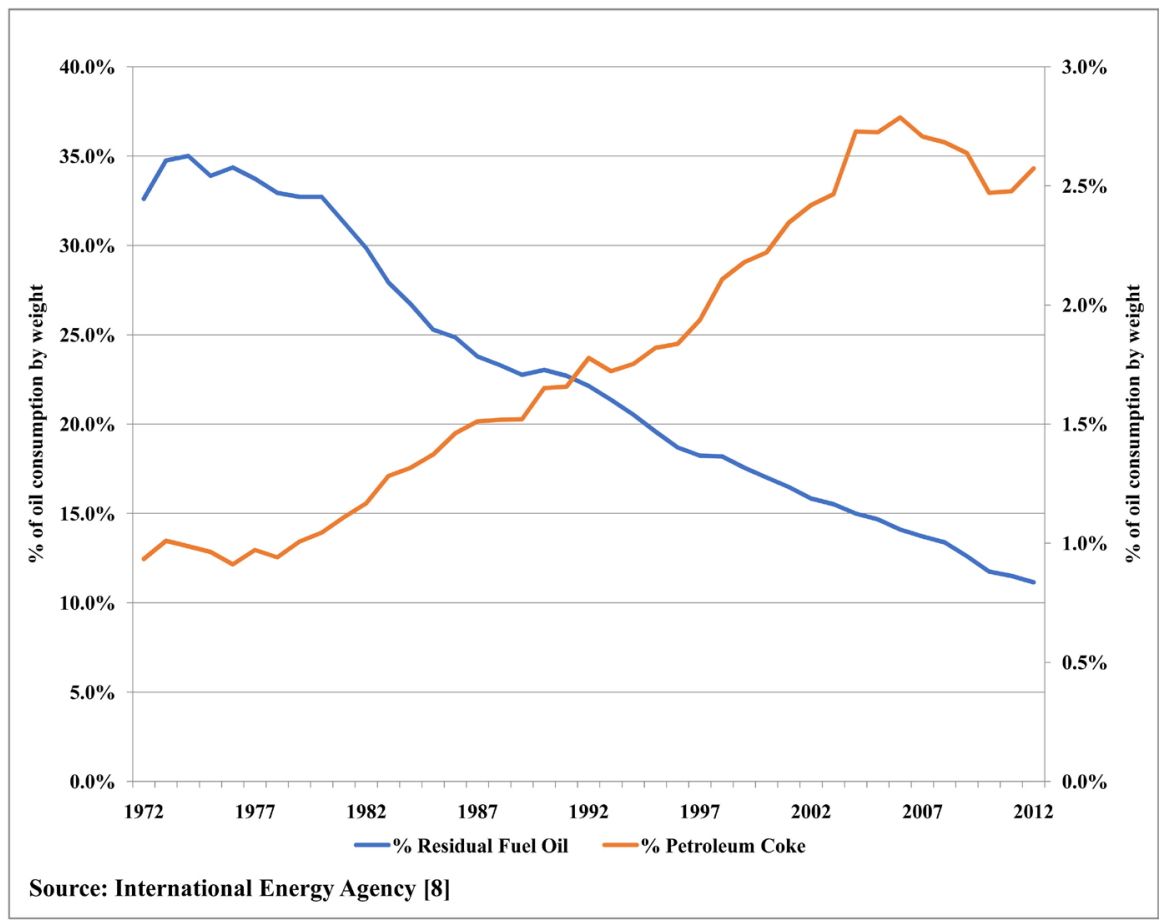

Figure 1. Percentage of residual fuel oil and petroleum coke by weight. 


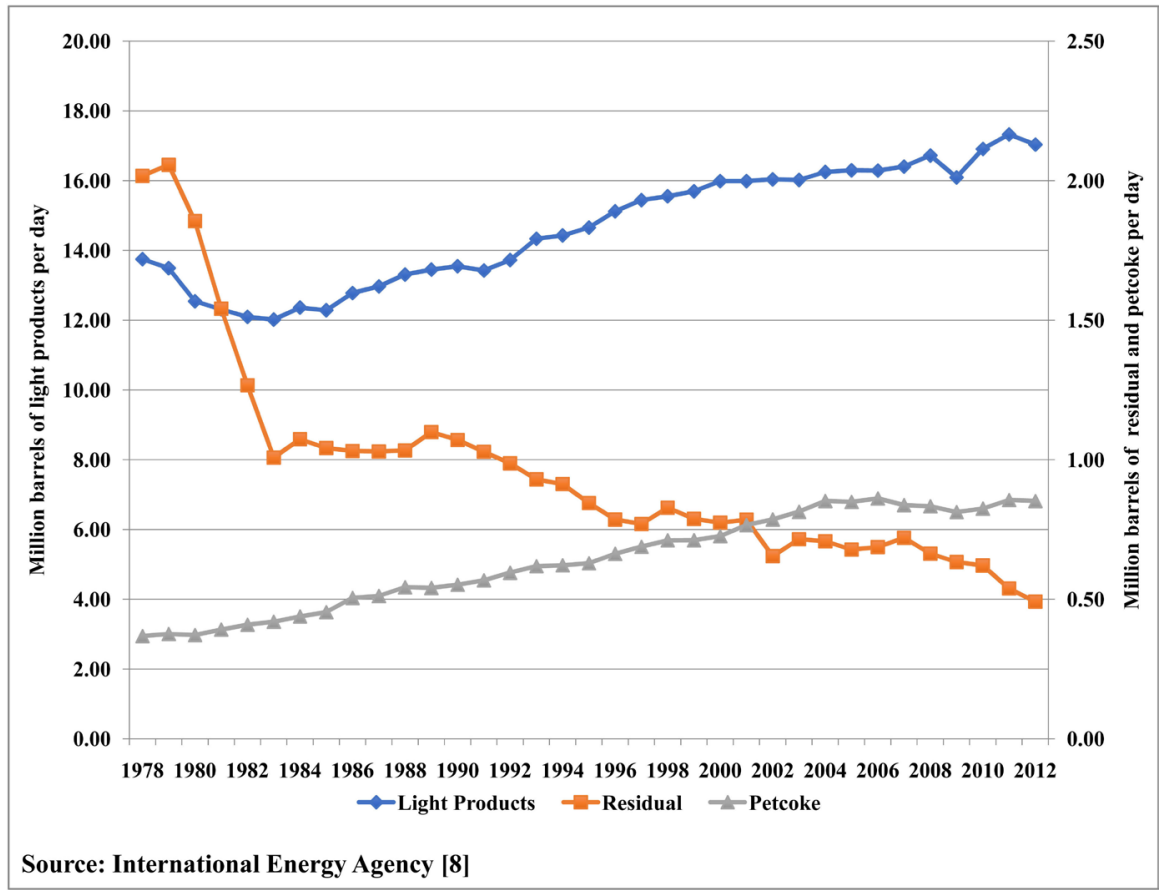

Figure 2. US Production of light products, residual fuel oil, and petroleum coke.

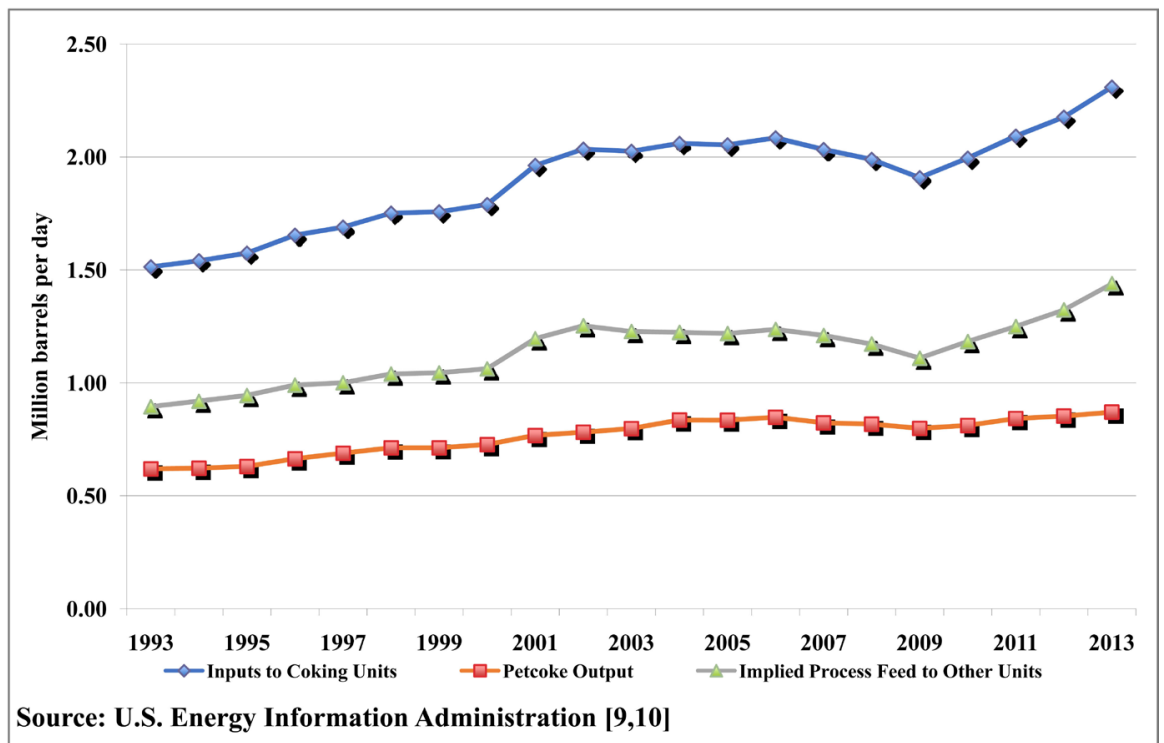

Figure 3. US Coker throughput and production of other products.

thousand barrels per day. The difference between these gross inputs and coke output is the implied process feed to other refinery units, which increased from 0.9 to 1.4 mmbd between 1993 and 2013 .

\section{The Market Model}

As the previous discussion demonstrates, the operation of petroleum cokers plays an important role in the production of refined petroleum products. Local bans on the shipment of petroleum coke would likely raise the cost of shipping 
and could disrupt refinery operations by backing up petroleum coke at refineries. If refiners cannot ship petroleum coke, supplies would quickly exceed on-site storage capacity, forcing either a shutdown or curtailment of cokers or even the entire refinery. Curtailment of petroleum coker operations would cut supplies of feedstocks to other processing units, which would reduce production of many refined petroleum products (see Figure 2). As a result, prices for petroleum products would increase and imports and exports would adjust to restore market balance. Hence, limitations on coker operations in the US would likely affect world markets for refined petroleum products.

The magnitude of these market impacts depends upon the amount of coker capacity shutdown and the elasticities of demand and supply for refined petroleum products both in the US and the rest of the world. To estimate these elasticities, this study specifies and estimates a simplified model of world refined petroleum markets.

The model is built around the following market clearing identity in region $j$ for product $i$ in period $t$.

$$
Y_{i t}^{j}+M_{i t}^{j}+S_{i t-1}^{j}=Q_{i t}^{j}+X_{i t}^{j}+S_{i t}^{j}
$$

where $Y_{i t}^{j}$ is production, $M_{i t}^{j}$ is imports, $X_{i t}^{j}$ is exports, $S_{i t}^{j}$ are period ending inventories, and $Q_{i t}^{j}$ is consumption of refined petroleum product $i$ in region $j$ during period $t$. The left side of the equality in (1) represents availability or supply from current production, imports, and inventories carried over from the previous period. The right side of Equation (1) is the demand for the refined petroleum product i from current consumption, exports, and period ending inventories.

For a two region model, net exports (imports) from one region are equal to net imports (exports) from the other. Also, on an annual basis net changes in product inventories are a small fraction of total consumption and production. These arguments imply the following simplified market clearing identity that balances regional excess supply and demand:

$$
\left(Y_{i t}^{r}-Q_{i t}^{r}\right)-\left(Y_{i t}^{u}-Q_{i t}^{u}\right)=B_{i t}
$$

where " $u$ " denotes United States, "r" denotes the rest of the world, and where

$$
B_{i t}=\left(M_{i t}^{u}-X_{i t}^{u}\right)-\left(M_{i t}^{r}-X_{i t}^{r}\right)+\left(S_{i t}^{u}-S_{i t-1}^{u}\right)-\left(S_{i t}^{r}-S_{i t-1}^{r}\right)
$$

is a balancing term reflecting regional differences in net trade flows and inventories. This study does not explicitly model imports and exports between regions and net inventory changes because they are roughly equal apart from accounting differences. Changes in net trade and inventory flows, however, can be calculated from differences in excess demand and supply between the two regions. Hence, Equation (2) is the market clearing identity for each refined petroleum product market. With models for production and consumption that depend upon price among other factors, Equation (2) can be solved for the equilibrium price that balances excess supply in one region with excess demand in the other. The response of prices and net trade flows to supply and demand shocks, there- 
fore, can be modeled in a straightforward manner.

Given the absence of fuel switching capability, apart from the sectors, such as electric power generation that face competition from other fuels, the demand for refined petroleum products is very price inelastic in the short-run, determined by the utilization of fixed stocks of energy consuming durable equipment, such as automobiles, trucks, ships, and aircraft. As these stocks of vehicles adjust over time in response to prices and income, the price and income elasticities should be larger.

Given these considerations, the classic partial adjustment model is often used to model the demand for refined petroleum products in which consumption responds to market shocks with a lag. For this study, demand is postulated to depend upon real product price, real gross domestic product, and a time trend to reflect efficiency improvements in the energy-using capital stock. The partial adjustment demand models take the following form:

$$
Q_{i t}^{j}=\alpha_{i}+\beta_{i}^{j} P_{i t}^{j}+\gamma_{i}^{j} I_{t}^{j}+\tau_{t}^{j} T+\lambda_{t}^{j} Q_{i t-1}^{j}
$$

where $Q_{i t}^{j}$ and $P_{i t}^{j}$ are consumption and price respectively for product $i$ in period $\mathrm{t}$ in region $j, I_{t}^{j}$ is real gross domestic product in region $\mathrm{j}$ in period $t, T$ is a time trend, and $\alpha_{i}^{j}, \beta_{i}^{j}, \gamma_{i}^{j}, \tau_{t}^{j}, \lambda_{t}^{j}$ are unknown parameters to be estimated. For residual fuel oil and petroleum coke, prices for natural gas and coal are included because these products are potential substitutes. A linear form rather than log-linear functional form is adopted to facilitate solution for equilibrium prices and to allow the price and income elasticities to vary over the data sample.

A distributed lagged demand model, suggested by Cuddington and Dagher [11], is also estimated and takes the following form:

$$
Q_{i t}^{j}=\alpha_{i}+\beta_{i}^{j} P_{i t}^{j}+\beta_{i 1}^{j} P_{i t-1}^{j}+\gamma_{i}^{j} I_{t}^{j}+\gamma_{i 1}^{j} I_{t-1}^{j}+\tau_{t}^{j} T+\lambda_{t}^{j} Q_{i t-1}^{j}+\lambda_{t 1}^{j} Q_{i t-2}^{j}
$$

The results for this distributed lag model and the partial adjustment model are discussed below.

On the supply side, the seven product categories are classified into two groups: primary products and secondary products. The four primary products include gasoline, distillate fuel oil, aviation fuels, and liquid petroleum gases. For the first three products, production is hypothesized to depend upon crack spreads, which are defined as the difference between the product price and the price of crude oil inputs:

$$
Y_{i t}^{j}=\eta_{i}^{j}+\delta_{i}^{j}\left(P_{i t}^{j}-C_{t}^{j}\right)+\psi_{i}^{j} T, \forall i=1,2,3,4
$$

where $Y_{i t}^{j}$ and $P_{i t}^{j}$ are defined as above, $C_{t}^{j}$ is the price of crude oil in region $j$, and $\eta_{i}^{j}, \delta_{i t}^{j}$ and $\psi_{i}^{j}$ are unknown parameters to be estimated while the product index $i$ here includes the first three fuels, gasoline, distillate fuel oil, and aviation fuels. The time trend reflects technological change in refined petroleum production. Liquid petroleum gases are produced at petroleum refineries and from natural gas processing plants that produce ethane, butane, iso-butane, natural gasoline, and pentanes, which are the main constituents of liquid petroleum gases, also known as natural gas liquids. Accordingly, for this product class, the 
spread between LPG prices and natural gas prices or the so-called fractionation spread or "frac spread" for short replaces the crack-spread in (6).

The production levels of the remaining three products-residual fuel oil, petroleum coke, and other petroleum products-are determined on the basis of production of the primary production:

$$
Y_{i t}^{j}=\eta_{i}^{j}+\delta_{i}^{j} \sum_{i=1}^{3} Y_{i t}^{j}+\psi_{i}^{j} T, \quad \forall i=5,6,7
$$

where the summation in (7) includes gasoline, distillate fuel oil, and aviation fuels.

The entire model includes 28 behavioral equations-the seven demand and seven supply functions for both the United States and the rest of the world. A discussion of the data sample used to estimate these supply and demand models and trends in production and consumption, prices, and trade balances now follows.

\section{Data Sample}

Observations for production and consumption of refined petroleum products are available from the International Energy Agency [8]. The definitions of the product aggregates are summarized in Table 1 . Given the availability of price data, our sample is from 1978 to 2012. Prices used in this study are from the Energy Information Administration [12] for the US and from International Energy Agency [13] for the rest of the world. Real gross domestic product (GDP) and the corresponding price deflators for the two regions are from the World Bank [14]. Real prices for gasoline, distillate, and residual fuel oil for the rest of the world are calculated from the IEA [13] and US EIA [12]. Prices for jet fuel, other petroleum products, liquid petroleum gases, and petroleum coke for the rest of the world are equal to the corresponding US retail prices deflated by the

Table 1. Definitions of product aggregates.

$\begin{array}{cc}\text { Gasoline } & \text { Residual Fuel Oil } \\ \text { Motor Gasoline } & \text { Residual fuel oil } \\ \text { Bio-gasoline (ethanol) } & \text { Bunker fuel oil } \\ \text { Gasoline additives } & \text { Liquid petroleum gases } \\ \text { Other liquid biofuels } & \text { Liquid petroleum gases } \\ \text { Distillate } & \text { Ethane } \\ \text { Distillate fuel oil } & \text { Natural gas liquids } \\ \text { Biodiesel } & \text { Other petroleum products } \\ \text { International marine diesel } & \text { White spirits } \\ \text { Aviation fuel } & \text { Naphtha } \\ \text { Aviation Gasoline } & \text { Lubricants } \\ \text { Kerosene type jet fuel } & \text { Bitumen or asphalt } \\ \text { Gasoline type jet fuel } & \text { Paraffin waxes } \\ \text { Other kerosene } & \text { Miscellaneous products }\end{array}$


implicit price deflator used to compute the real gasoline price index from IEA [13] for the rest of the world.

Trends in the consumption of petroleum products for the US and the rest of the world are displayed in Figure 4 and Figure 5. Gasoline is the largest product

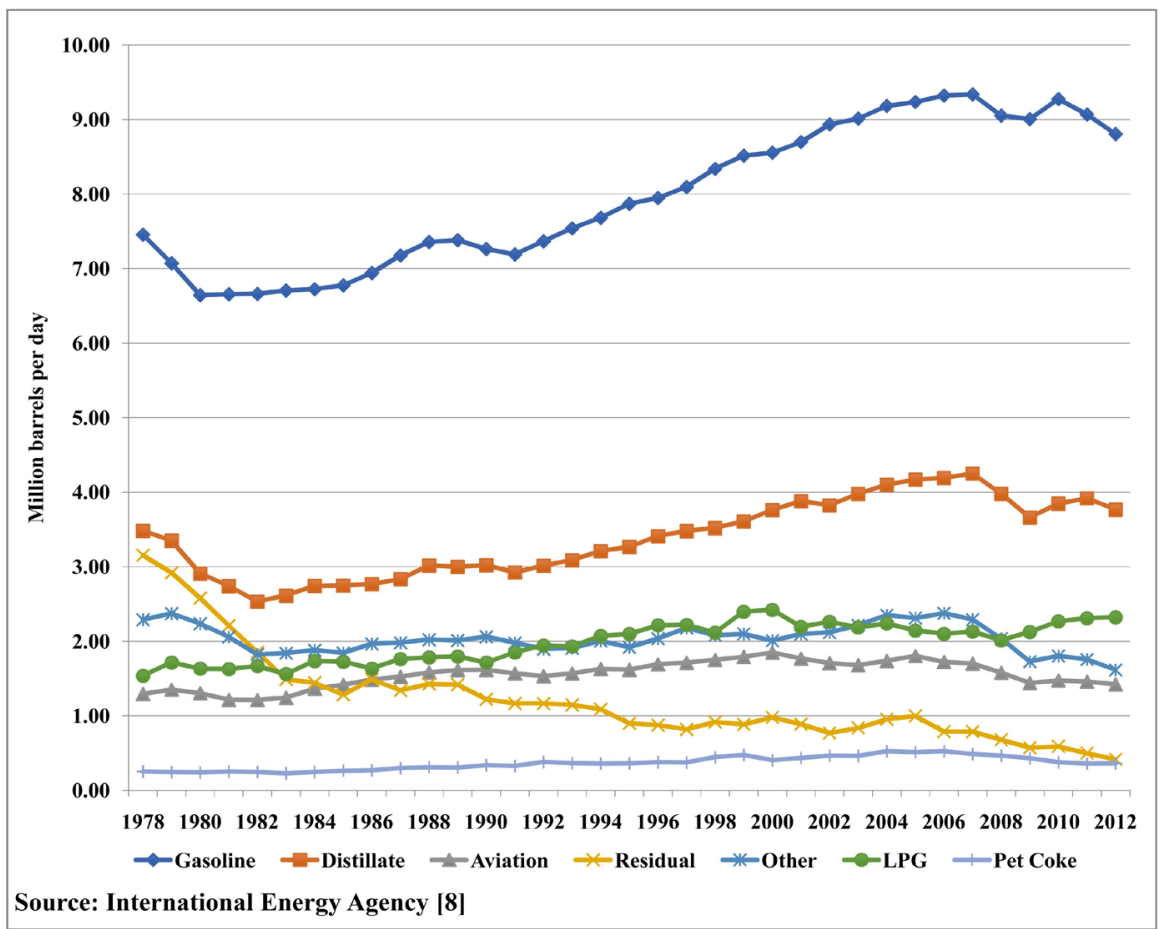

Figure 4. US consumption of refined petroleum products.

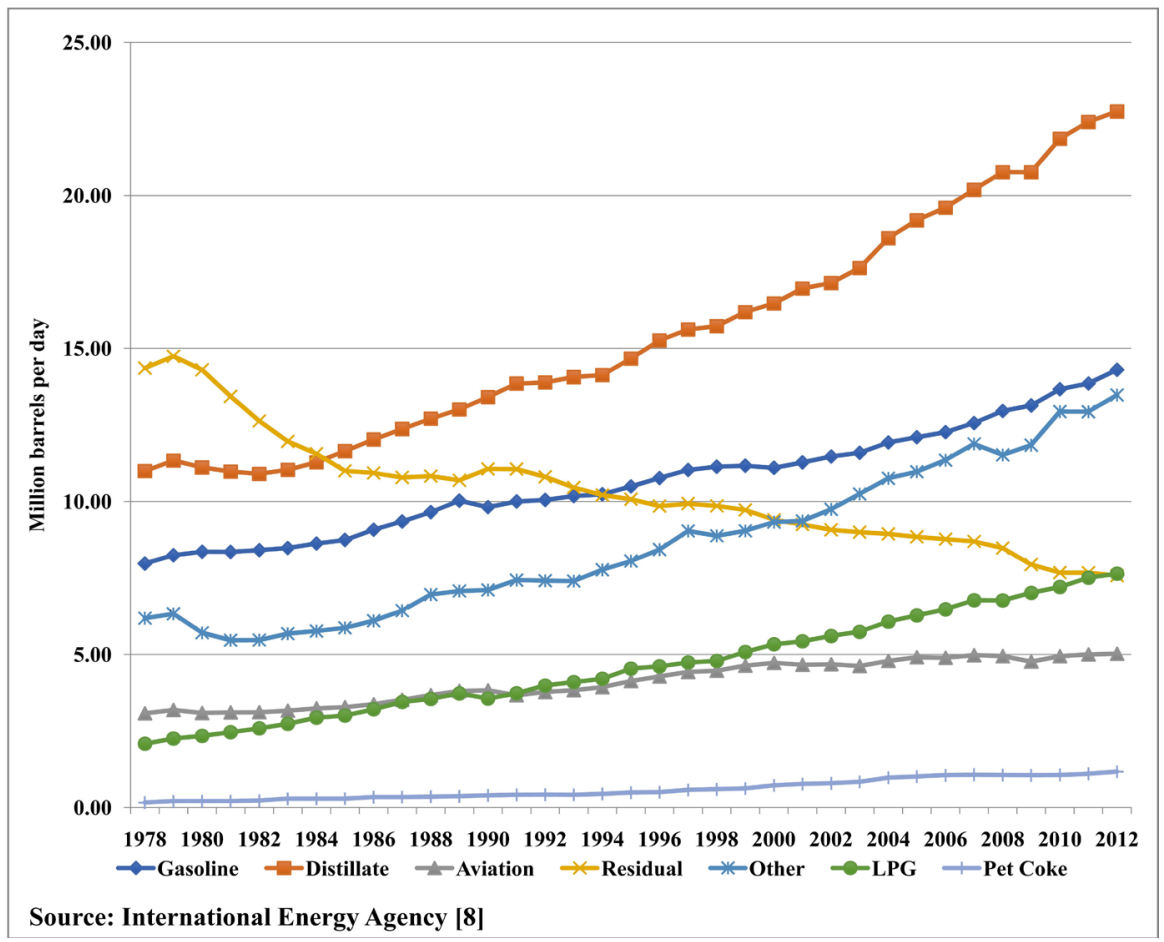

Figure 5. Rest of the world consumption of refined petroleum products. 
in the US, increasing from roughly 7.5 to $8.8 \mathrm{mmbd}$ from 1978 to 2012 while distillate fuel oil reigns supreme in the rest of the world, rising from 11.0 to 22.7 mmbd over the same period. Consumption of LPG, aviation fuels, and other petroleum products are the next largest categories. World petroleum coke consumption is about $1.5 \mathrm{mmbd}$ in 2012 with the US consuming about 24 percent of this amount.

\section{Econometric Findings}

Several econometric estimation methods and specifications were pursued to determine the robustness of the results. The first issue concerns the time series properties of the data. Accordingly, all data are checked for unit roots using the augmented Dickey-Fuller test. Real prices, production, and consumption were found to have unit roots. Therefore, all models were initially estimated in first differences. For these models, there were several elasticity estimates that were extremely small, which would have exaggerated the price impacts of reductions in petroleum coke production. The distributed lag models (5) were also estimated. Several of the own price elasticities of demand from the DL models were positive and some of the supply elasticities were unreasonable. The partial adjustment models of demand, therefore, were adopted.

Another important econometric issue involves the possibility of endogenous explanatory variables in the demand and supply models, specifically product and crude oil prices. Two supply side instrumental variables were used to estimate the models with two-stage least squares. The first is the sum of North Sea and Mexican crude oil production. Both of these areas have large conventional offshore fields with production determined largely by geological conditions. The second instrumental variable is the sum of crude oil production in Libya, Nigeria, and Iraq. This instrument represents supply shocks due to political events unrelated to oil market conditions, such as the Persian Gulf War of 1990-91, the Iraq war of 2003-2005, recurring conflicts in Nigeria, and the Libyan revolution during 2010 and 2011. All models were estimated with these two variables serving as instruments for real prices and crack spreads. The price and income elasticities are very similar to the ordinary least squares estimates presented below.

The parameter estimates for light refined petroleum product demand appear in Table 2. The estimated coefficients on prices and gross domestic product all have the correct signs in each of the two regions. The estimated probability values are generally lower for the United States, indicating a relatively greater degree of precision associated with the US estimates compared with those for the rest of the world. With the exception of liquid petroleum gases and aviation fuel demand for the rest of the world, all fuels have estimated trend coefficients that are negative and statistically significant. These significant trend effects reflect the combined effects of higher fuel efficiency standards, energy conservation by consumers (more efficient transport decisions) and more efficient engines and vehicle designs. The estimated trend coefficients for liquid petroleum gases 
Table 2. Parameter estimates for light petroleum product demand.

\begin{tabular}{|c|c|c|c|c|c|c|}
\hline \multirow{3}{*}{ Variable } & \multicolumn{3}{|c|}{ Rest-of-World } & \multicolumn{3}{|c|}{ United States } \\
\hline & \multicolumn{6}{|c|}{ Gasoline } \\
\hline & Estimate & T-Stat. & P-Values & Estimate & T-Stat. & P-Values \\
\hline Constant & 0.518 & 0.56 & 0.58 & 1.715 & 5.21 & 0.00 \\
\hline Price & -0.007 & -2.67 & 0.01 & -0.005 & -4.81 & 0.00 \\
\hline GDP & 0.147 & 4.04 & 0.00 & 0.310 & 4.00 & 0.00 \\
\hline Trend & -0.065 & -2.33 & 0.02 & -0.039 & -2.29 & 0.02 \\
\hline Lag Q & 0.775 & 5.31 & 0.00 & 0.544 & 6.13 & 0.00 \\
\hline $\mathrm{R}^{2}$ & 0.992 & & & 0.985 & & \\
\hline Durbin $\mathrm{H}$ & -0.129 & & 0.90 & 1.009 & & 0.31 \\
\hline \multirow[t]{2}{*}{ Unit Root } & -3.111 & & 0.06 & -3.398 & & 0.03 \\
\hline & \multicolumn{6}{|c|}{ Distillate Fuel or Gas Oil } \\
\hline Constant & 0.310 & 0.46 & 0.65 & -0.179 & -0.81 & 0.42 \\
\hline Price & -0.005 & -1.46 & 0.14 & -0.003 & -4.07 & 0.00 \\
\hline GDP & 0.371 & 3.81 & 0.00 & 0.370 & 4.12 & 0.00 \\
\hline Trend & -0.072 & -1.46 & 0.14 & -0.071 & -3.30 & 0.00 \\
\hline Lag Q & 0.471 & 3.93 & 0.00 & 0.419 & 3.35 & 0.00 \\
\hline $\mathrm{R}^{2}$ & 0.998 & & & 0.943 & & \\
\hline Durbin $\mathrm{H}$ & 1.186 & & 0.24 & -0.023 & & 0.98 \\
\hline \multirow[t]{2}{*}{ Unit Root } & -2.421 & & 0.34 & -2.734 & & 0.17 \\
\hline & \multicolumn{6}{|c|}{ Jet Fuel \& Kerosene } \\
\hline Constant & 0.700 & 2.14 & 0.03 & 0.270 & 1.86 & 0.06 \\
\hline Price & -0.002 & -1.92 & 0.05 & -0.002 & -5.08 & 0.00 \\
\hline GDP & 0.016 & 0.61 & 0.54 & 0.081 & 3.06 & 0.00 \\
\hline Trend & 0.007 & 0.39 & 0.70 & -0.018 & -2.48 & 0.01 \\
\hline Lag Q & 0.735 & 9.13 & 0.00 & 0.612 & 6.70 & 0.00 \\
\hline $\mathrm{R}^{2}$ & 0.972 & & & 0.824 & & \\
\hline Durbin $\mathrm{H}$ & 0.52 & & 0.60 & 0.869 & & 0.39 \\
\hline \multirow[t]{2}{*}{ Unit Root } & -2.975 & & 0.09 & -3.491 & & 0.02 \\
\hline & \multicolumn{6}{|c|}{ Liquid Petroleum Gases } \\
\hline Constant & -0.853 & -1.79 & 0.07 & 0.682 & 2.84 & 0.00 \\
\hline Price & -0.001 & -0.41 & 0.69 & -0.005 & -1.70 & 0.09 \\
\hline GDP & 0.119 & 2.21 & 0.03 & 0.053 & 2.21 & 0.03 \\
\hline D2012 & & & & -0.083 & -2.70 & 0.01 \\
\hline Lag Q & 0.621 & 3.39 & 0.00 & 0.561 & 3.48 & 0.00 \\
\hline $\mathrm{R}^{2}$ & 0.996 & & & 0.869 & & \\
\hline Durbin H & 0.404 & & 0.69 & -0.587 & & 0.56 \\
\hline Unit Root & -3.387 & & 0.03 & -2.285 & & 0.44 \\
\hline
\end{tabular}

$\mathrm{t}$ and $\mathrm{p}$-values are computed based upon heteroscedastic standard errors. 
demand are insignificant and, therefore, omitted. Unlike the other light petroleum products, a significant portion of LPG demand is derived from the production of petrochemicals. The Durbin $\mathrm{h}$ statistics and the corresponding p-values indicate the absence of autocorrelation in the residuals. Likewise, the unit root tests on the residuals and their corresponding $\mathrm{p}$-values indicate low probabilities for unit roots in the residuals.

The parameter estimates for heavy petroleum products appear below in Table 3. The own price elasticities of demand are all statistically significant. The GDP elasticities are all positive and also significant. During the model simulation to evaluate the fit of the model, several outliers were discovered for the petroleum coke data. As a result, dummy variables for 2000 and 2004 were included in the petroleum coke demand models. The estimates for the other explanatory variables, however, did not change substantially from the model without these dummy variables.

The findings of fuel switching for residual fuel oil and petroleum coke are mixed. For the US, coal is found to be a substitute with residual fuel oil but the probability value is 0.11 (see Table 3). For the rest of the world, distillate fuel oil is found to be a substitute for residual fuel oil but the probability value is also 0.11 . The trend terms in the demand for residual fuel oil are significant in both regions. Natural gas prices are somewhat significant in the petroleum coke demand model for the rest of the world with a probability value of 0.06 , but were not found to be significant for the US market.

The short and long run price elasticities of demand in Table 4 are evaluated at the sample means. As expected, the demands for these fuels are very price inelastic. For example, the short-run gasoline price elasticity of demand is -0.06 and -0.05 in the rest of the world and the US respectively. In the long run, these elasticities are -0.26 and -0.11 respectively. While the price elasticities of demand for diesel in the US are very close to those for gasoline, the demand for diesel fuel in the rest of the world is considerably less responsive to price with short and long price elasticities of -0.02 and -0.05 respectively. The demand for aviation fuels shows slightly greater sensitivity to price, particularly for the long run in the US, with an elasticity of -0.22 (see Table 4 ). The GDP elasticities are positive as expected and are considerably larger in magnitude compared with the price elasticities of demand. The GDP elasticities for gasoline and diesel are highly significant, indicating a close linkage between fuel demand and economic growth.

The US demand for residual fuel oil is considerably more responsive to price with short-run own price elasticity of -0.19 and a long-run estimate of -0.79 (Table 4). The demand for residual fuel oil in the rest of the world shows somewhat less price responsiveness compared to the US with short and long run price elasticities of -0.13 and -0.23 respectively. The price elasticities of US demand for other petroleum products is also very price inelastic with estimates of -0.09 in the short-run and -0.17 in the long run. 
Table 3. Parameter estimates for heavy petroleum product demand.

\begin{tabular}{|c|c|c|c|c|c|c|}
\hline \multirow{3}{*}{ Variable } & \multicolumn{3}{|c|}{ Rest-of-World } & \multicolumn{3}{|c|}{ United States } \\
\hline & \multicolumn{6}{|c|}{ Residual Fuel Oil } \\
\hline & Estimate & T-Stat. & P-Values & Estimate & T-Stat. & P-Values \\
\hline Constant & 5.252 & 2.47 & 0.01 & -0.813 & -1.72 & 0.09 \\
\hline Price & -0.021 & -2.79 & 0.01 & -0.006 & -2.12 & 0.03 \\
\hline Dist. Price & 0.017 & 1.62 & 0.11 & & & \\
\hline Coal Price & & & & 0.219 & 1.60 & 0.11 \\
\hline GDP & 0.112 & 2.13 & 0.03 & 0.150 & 2.50 & 0.01 \\
\hline Trend & -0.142 & -3.83 & 0.00 & -0.037 & -2.13 & 0.03 \\
\hline Lagged Q & 0.437 & 2.60 & 0.01 & 0.759 & 10.62 & 0.00 \\
\hline $\mathrm{R}^{2}$ & 0.985 & & & 0.916 & & \\
\hline Durbin $\mathrm{H}$ & 1.318 & & 0.19 & 1.143 & & 0.25 \\
\hline \multirow[t]{2}{*}{ Unit Root } & -4.123 & & 0.00 & -2.840 & & 0.13 \\
\hline & \multicolumn{6}{|c|}{ Petroleum Coke } \\
\hline Constant & -0.295 & -2.50 & 0.01 & -0.076 & -1.44 & 0.15 \\
\hline Price & -0.003 & -2.53 & 0.01 & -0.006 & -3.74 & 0.00 \\
\hline NG Price & 0.001 & 1.89 & 0.06 & & & \\
\hline GDP & 0.022 & 3.07 & 0.00 & 0.070 & 5.19 & 0.00 \\
\hline Trend & & & & -0.017 & -4.96 & 0.00 \\
\hline Lagged Q & 0.452 & 2.41 & 0.02 & 0.388 & 2.92 & 0.00 \\
\hline D2004 & 0.083 & 7.34 & 0.00 & & & \\
\hline D2000 & & & & -0.082 & -12.34 & 0.00 \\
\hline $\mathrm{R}^{2}$ & 0.990 & & & 0.850 & & \\
\hline Durbin $\mathrm{H}$ & 2.159 & & 0.03 & -0.878 & 0.38 & \\
\hline \multirow[t]{2}{*}{ Unit Root } & -2.351 & & 0.39 & -2.678 & 0.20 & \\
\hline & \multicolumn{6}{|c|}{ Other Petroleum Products } \\
\hline Constant & -1.710 & -2.00 & 0.05 & 0.015 & 0.08 & 0.93 \\
\hline Price & -0.007 & -2.65 & 0.01 & -0.003 & -4.97 & 0.00 \\
\hline GDP & 0.384 & 4.23 & 0.00 & 0.267 & 3.73 & 0.00 \\
\hline Trend & -0.128 & -2.15 & 0.03 & -0.073 & -3.66 & 0.00 \\
\hline Lag Q & 0.382 & 3.03 & 0.00 & 0.441 & 4.08 & 0.00 \\
\hline $\mathrm{R}^{2}$ & 0.991 & & & 0.773 & & \\
\hline Durbin $\mathrm{H}$ & 2.989 & & 0.00 & 0.076 & 0.94 & \\
\hline Unit Root & -2.353 & & 0.39 & -2.805 & 0.14 & \\
\hline
\end{tabular}

$\mathrm{t}$ and $\mathrm{p}$-values are computed based upon heteroscedastic standard errors. 
Table 4. Petroleum product demand elasticities evaluated at sample means.

\begin{tabular}{|c|c|c|c|c|c|c|c|c|}
\hline \multirow{3}{*}{ Gasoline } & \multicolumn{4}{|c|}{ Own Price Elasticities } & \multicolumn{4}{|c|}{ GDP Elasticities } \\
\hline & \multicolumn{2}{|c|}{ Rest-of-World } & \multicolumn{2}{|c|}{ United States } & \multicolumn{2}{|c|}{ Rest-of-World } & \multicolumn{2}{|c|}{ United States } \\
\hline & SR & LR & SR & LR & SR & LR & SR & LR \\
\hline Estimate & -0.06 & -0.26 & -0.05 & -0.11 & 0.36 & 1.61 & 0.39 & 0.84 \\
\hline T-Stat. & -2.67 & -1.32 & -4.81 & -2.82 & 4.04 & 1.68 & 4.00 & 5.85 \\
\hline P-Values & 0.01 & 0.19 & 0.00 & 0.00 & 0.00 & 0.09 & 0.00 & 0.00 \\
\hline \multicolumn{9}{|l|}{ Distillate } \\
\hline Estimate & -0.02 & -0.05 & -0.06 & -0.10 & 0.63 & 1.19 & 1.08 & 1.87 \\
\hline T-Stat. & -1.46 & -1.37 & -4.07 & -2.88 & 3.81 & 5.31 & 4.12 & 7.13 \\
\hline P-Values & 0.14 & 0.17 & 0.00 & 0.00 & 0.00 & 0.00 & 0.00 & 0.00 \\
\hline \multicolumn{9}{|c|}{ Aviation Fuels } \\
\hline Estimate & -0.03 & -0.10 & -0.08 & -0.22 & 0.10 & 0.38 & 0.51 & 1.31 \\
\hline T-Stat. & -1.92 & -1.83 & -5.08 & -7.09 & 0.61 & 0.62 & 3.06 & 2.99 \\
\hline P-Values & 0.05 & 0.07 & 0.00 & 0.00 & 0.54 & 0.54 & 0.00 & 0.00 \\
\hline \multicolumn{9}{|l|}{ Residual } \\
\hline Estimate & -0.13 & -0.23 & -0.19 & -0.79 & 0.05 & 0.09 & 1.29 & 5.33 \\
\hline T-Stat. & -2.79 & -4.43 & -2.12 & -1.70 & 1.62 & 2.34 & 2.50 & 2.66 \\
\hline P-Values & 0.01 & 0.00 & 0.03 & 0.09 & 0.11 & 0.02 & 0.01 & 0.01 \\
\hline \multicolumn{9}{|c|}{ Other Products } \\
\hline Estimate & -0.07 & -0.12 & -0.09 & -0.17 & 1.17 & 1.90 & 1.31 & 2.34 \\
\hline T-Stat. & -2.65 & -2.11 & -4.97 & -4.05 & 4.23 & 4.25 & 3.73 & 6.72 \\
\hline P-Values & 0.01 & 0.03 & 0.00 & 0.00 & 0.00 & 0.00 & 0.00 & 0.00 \\
\hline \multicolumn{9}{|l|}{ LPG } \\
\hline Estimate & -0.01 & -0.03 & -0.08 & -0.18 & 0.55 & 1.45 & 0.24 & 0.55 \\
\hline T-Stat. & -0.41 & -0.38 & -1.70 & -2.25 & 2.21 & 16.90 & 2.21 & 4.41 \\
\hline P-Values & 0.69 & 0.70 & 0.09 & 0.02 & 0.03 & 0.00 & 0.03 & 0.00 \\
\hline \multicolumn{9}{|l|}{ PetCoke } \\
\hline Estimate & -0.05 & -0.09 & -0.17 & -0.28 & 0.90 & 1.64 & 1.89 & 3.09 \\
\hline T-Stat. & -2.53 & -2.33 & -3.74 & -6.79 & 3.07 & 21.35 & 5.19 & 5.64 \\
\hline P-Values & 0.01 & 0.02 & 0.00 & 0.00 & 0.00 & 0.00 & 0.00 & 0.00 \\
\hline
\end{tabular}

$\mathrm{t}$ and $\mathrm{p}$-values are computed based upon heteroscedastic standard errors.

The results from estimating the production models for the primary products appear in Table 5. The models are estimated with a correction for autocorrelation using maximum likelihood estimation. For the rest of the world, the crack spread is measured by the difference in the respective wholesale prices for products in Europe less the price for Brent crude oil. The spread between product prices and the price for West Texas Intermediate crude oil is used for the crack spread in the US models. All three coefficients on the crack spreads are positive 
Table 5. Parameter estimates for primary petroleum product supply.

\begin{tabular}{|c|c|c|c|c|c|c|}
\hline & \multicolumn{3}{|c|}{ Rest-of-World } & \multicolumn{3}{|c|}{ United States } \\
\hline & Estimate & T-Stats & P-Values & Estimate & T-Stats & P-Values \\
\hline & \multicolumn{6}{|c|}{ Gasoline } \\
\hline Constant & 7.474 & 46.26 & 0.00 & 6.431 & 41.03 & 0.00 \\
\hline Crack Spread & 0.032 & 2.71 & 0.01 & 0.048 & 4.02 & 0.00 \\
\hline Trend & 0.170 & 27.06 & 0.00 & 0.039 & 2.97 & 0.01 \\
\hline RVP1 & & & & 0.165 & 1.19 & 0.25 \\
\hline RVP2 & & & & 0.305 & 1.92 & 0.07 \\
\hline RVP3 & & & & 0.840 & 4.06 & 0.00 \\
\hline Rho & 0.533 & 3.10 & 0.00 & & & \\
\hline $\mathrm{R}^{2}$ & 0.990 & & & 0.909 & & \\
\hline \multirow[t]{2}{*}{ Durbin Watson } & 1.635 & & & 2.031 & & \\
\hline & \multicolumn{6}{|c|}{ Distillate Fuel } \\
\hline Constant & 8.697 & 30.56 & 0.00 & 2.125 & 55.90 & 0.00 \\
\hline Crack Spread & 0.026 & 3.65 & 0.00 & 0.006 & 2.28 & 0.02 \\
\hline Trend & 0.362 & 29.89 & 0.00 & 0.063 & 25.81 & 0.00 \\
\hline Rho & 0.720 & 5.51 & 0.00 & -0.178 & -0.90 & 0.37 \\
\hline $\mathrm{R}^{2}$ & 0.996 & & & 0.978 & & \\
\hline \multirow[t]{3}{*}{ Durbin Watson } & 1.445 & & & 2.010 & & \\
\hline & \multicolumn{6}{|c|}{ Aviation Fuels } \\
\hline & Estimate & T-Statistics & P-Values & Estimate & T-Statistics & P-Values \\
\hline Constant & 2.982 & 16.08 & 0.00 & 1.517 & 12.31 & 0.00 \\
\hline Crack Spread & 0.006 & 1.87 & 0.06 & 0.005 & 3.08 & 0.00 \\
\hline Trend & 0.072 & 9.35 & 0.00 & -0.002 & -0.42 & 0.67 \\
\hline Rho & 0.793 & 7.04 & 0.00 & 0.897 & 11.40 & 0.00 \\
\hline $\mathrm{R}^{2}$ & 0.974 & & & 0.646 & & \\
\hline \multirow[t]{3}{*}{ Durbin Watson } & 1.491 & & & 1.709 & & \\
\hline & \multicolumn{6}{|c|}{ Liquid Petroleum Gases } \\
\hline & Estimate & T-Statistics & P-Values & Estimate & T-Statistics & P-Values \\
\hline Constant & 1.375 & 8.30 & 0.00 & 1.777 & 11.99 & 0.00 \\
\hline Price/Frac. Spread & 0.015 & 3.45 & 0.00 & 0.011 & 1.04 & 0.30 \\
\hline Trend & 0.276 & 30.01 & 0.00 & 0.018 & 2.67 & 0.01 \\
\hline D2008 & -0.203 & -1.68 & 0.09 & & & \\
\hline D2012 & 0.277 & 1.95 & 0.05 & & & \\
\hline D1991 & & & & -0.146 & -2.88 & 0.00 \\
\hline Rho & 0.644 & 4.30 & 0.00 & 0.812 & 7.22 & 0.00 \\
\hline $\mathrm{R}^{2}$ & 0.997 & & & 0.997 & & \\
\hline Durbin Watson & 1.661 & & & 1.661 & & \\
\hline
\end{tabular}

$\mathrm{t}$ and $\mathrm{p}$-values are computed based upon heteroscedastic standard errors. 
for the rest of the world, as expected. The crack spreads for gasoline and distillate are highly significant while the aviation fuel crack spread p-value is 6.1 percent. The coefficients for trend in these three primary fuel production models are positive and highly significant, consistent with the trend toward expanded light petroleum production observed by Leffler [1].

The same models are estimated for the US and the results are also presented in Table 5. The crack spreads for gasoline, distillate, and jet fuel are positive and highly significant. The gasoline production model is estimated for conventional gasoline production excluding ethanol because ethanol is produced in separate plants and blended with conventional gasoline to meet environmental regulations. For the purposes of this analysis, ethanol production, therefore, is exogenous. Three dummy variables for the phased implementation of environmental standards for Reid Vapor Pressure (RVP) are also included as explanatory variables based upon the study by Lidderdale [15].

The production models for liquid petroleum gases also appear in Table 5. The fractionation spread was not possible to compute for the rest of the world so the price for liquid petroleum gases was used and found to be positive and significant. The coefficient on the fractionation spread for the US is positive but the low t-statistic and relatively high probability value indicates that it may not be a significant determinant of US LPG production. The production models for LPG in both regions show a positive and significant trend coefficient. Like the demand models for petroleum coke, dummy variables are included to control for outliers.

The parameter estimates for the production of secondary products appear in Table 6. For the rest of the world, the coefficients for primary production are positive for all secondary petroleum products, but the estimate for petroleum coke is rather imprecise. The trend terms for other products and petroleum coke are positive but negative for residual fuel oil. For the US, primary production is positively related to production of other petroleum products and petroleum coke. The trend coefficients for residual fuel oil and other petroleum product are negative and significant while the petroleum coke trend effect is positive and significant.

The supply elasticities are computed from these estimates and evaluated at the mean of the data (see Table 7). Like demand, primary production is very price inelastic.

For example, for a 10 percent change in price, production of gasoline outside the US increases 1.22 percent. Five out of six elasticities of secondary production with respect to primary production are positive and four of these are statistically significant.

A within sample static model simulation is conducted to determine the accuracy of the model. The mean squared errors for demand and supply for the three largest product categories-gasoline, distillate, and aviation fuels-are within one and three percent. The mean squared errors for prices for these three prod- 
uct aggregates are higher because small errors in demand or supply occasionally compound. The mean squared errors for the remaining four product aggregates are larger but also display a lack of any systematic bias, see Appendix A.

\section{Market Impacts of Shutting Down US Production of Petroleum Coke}

If petroleum coke production is shutdown in the US, residual fuel oil is the only outlet for the refinery residue. Using an engineering-economic linear programming model of the US refining sector described by Jacobs [16], Jenkins [17] estimates how the composition of refined petroleum production would be affected if petroleum coke production capacity in the US is shutdown.

The econometric model developed above is used to estimate the market

Table 6. Parameter estimates for secondary petroleum product supply.

\begin{tabular}{|c|c|c|c|c|c|c|}
\hline & \multicolumn{3}{|c|}{ Rest-of-World } & \multicolumn{3}{|c|}{ United States } \\
\hline & Estimate & T-Stats & $P$-Values & Estimate & T-Stats & $P$-Values \\
\hline & \multicolumn{6}{|c|}{ Residual Fuel Oil } \\
\hline Constant & 7.082 & 4.04 & 0.00 & 1.425 & 4.42 & 0.00 \\
\hline Primary Output & 0.340 & 3.74 & 0.00 & -0.017 & -0.52 & 0.60 \\
\hline Trend & -0.360 & -6.05 & 0.00 & -0.018 & -3.48 & 0.00 \\
\hline Rho & 0.595 & 3.39 & 0.00 & 0.523 & 2.93 & 0.00 \\
\hline $\mathrm{R}^{2}$ & 0.977 & & & 0.939 & & \\
\hline \multirow[t]{2}{*}{ Durbin Watson } & 1.969 & & & 1.785 & & \\
\hline & \multicolumn{6}{|c|}{ Other Petroleum Products } \\
\hline Constant & -2.155 & -1.01 & 0.31 & 0.625 & 1.34 & 0.18 \\
\hline Primary Output & 0.212 & 1.91 & 0.06 & 0.139 & 2.92 & 0.00 \\
\hline Trend & 0.048 & 0.66 & 0.51 & -0.023 & -3.08 & 0.00 \\
\hline Rho & 0.293 & 1.39 & 0.17 & 0.283 & 1.35 & 0.18 \\
\hline $\mathrm{R}^{2}$ & 0.975 & & & 0.394 & & \\
\hline \multirow[t]{2}{*}{ Durbin Watson } & 1.757 & & & 1.904 & & \\
\hline & \multicolumn{6}{|c|}{ Petroleum Coke } \\
\hline Constant & -0.548 & -1.87 & 0.06 & 0.069 & 0.63 & 0.53 \\
\hline Primary Output & 0.020 & 1.37 & 0.17 & 0.033 & 3.07 & 0.00 \\
\hline Trend & 0.016 & 1.58 & 0.12 & 0.009 & 4.98 & 0.00 \\
\hline D2006 & 0.059 & 3.06 & 0.00 & & & \\
\hline D2004 & 0.879 & 8.67 & 0.00 & 0.022 & 2.16 & 0.03 \\
\hline Rho & 0.984 & & & 0.824 & 7.72 & 0.00 \\
\hline $\mathrm{R}^{2}$ & 1.726 & & & 0.987 & & \\
\hline Durbin Watson & & & & 1.424 & & \\
\hline
\end{tabular}

$\mathrm{t}$ and $\mathrm{p}$-values are computed based upon heteroscedastic standard errors. 
Table 7. Petroleum product supply elasticities evaluated at sample means.

\begin{tabular}{cccccc}
\hline & \multicolumn{2}{c}{ Price } & & \multicolumn{2}{c}{ Primary Production } \\
\hline Gasoline & ROW & US & Residual & ROW & US \\
\hline Estimate & 0.122 & 0.007 & Estimate & 1.076 & -0.275 \\
T-Stats & 2.705 & 4.024 & T-Stats & 3.740 & -0.520 \\
P-Values & 0.007 & 0.000 & P-Values & 0.000 & 0.603 \\
Distillate & & & Other Products & & \\
Estimate & 0.073 & 0.002 & Estimate & 1.186 & 0.938 \\
T-Stats & 3.648 & 2.279 & T-Stats & 1.910 & 2.918 \\
P-Values & 0.000 & 0.023 & P-Values & 0.056 & 0.004 \\
Aviation Fuels & & & Petcoke & & \\
Estimate & 0.067 & 0.004 & Estimate & 1.523 & 0.604 \\
T-Stats & 1.874 & 3.080 & T-Stats & 1.367 & 3.072 \\
P-Values & 0.061 & 0.002 & P-Values & 0.172 & 0.002 \\
LPG & & & & & \\
Estimate & 0.060 & 0.034 & & & \\
T-Stats & 3.447 & 1.040 & 0.299 & &
\end{tabular}

$\mathrm{t}$ and $\mathrm{p}$-values are computed based upon heteroscedastic standard errors.

impacts of these changes, assuming that they are phased in over a two-year period. The model is solved over the last four years of the sample, 2009-2012, with and without these changes. Production, consumption, and price by region and product are compared below in the Table 8 . The fifth column in Table 8 reports the changes in refined petroleum production estimated by Jenkins [17]. Given our assumption of a two-year phase out of petroleum coke production, residual fuel oil production increases by $1.59 \mathrm{mmbd}$ in year one and by $3.18 \mathrm{mmbd}$ in year two. Production of all other petroleum products declines with the largest reductions for aviation fuels, petroleum coke, and other petroleum products.

Even though lower demand both here and abroad and additional production overseas offsets some of these US output losses, equilibrium prices for petroleum products other than residual fuel oil increase substantially, with the second largest increases occurring for aviation fuels. Under a shutdown of petroleum coke production in the US, the market for residual fuel oil is flooded so that prices collapse. Greater primary production overseas due to higher prices for primary products exacerbates the situation. Most of the additional residual fuel oil production is sold to the rest of the world. Finally, the shutdown of petroleum coke production has a pronounced impact on petroleum coke markets as illustrated in Table 8. Since the US is the dominant producer, petroleum coke prices more than triple under the shutdown of US production. While substitution to coal and other fuels would take place, consumers of petroleum coke would face much 
Table 8. Simulated market impacts of phasing out US petroleum coke production.

\begin{tabular}{|c|c|c|c|c|c|}
\hline \multirow[b]{2}{*}{ Year } & \multicolumn{2}{|c|}{$\begin{array}{c}\text { Demand Changes million } \\
\text { barrels per day }\end{array}$} & \multicolumn{2}{|c|}{$\begin{array}{c}\text { Supply Changes million } \\
\text { barrels per day }\end{array}$} & \multirow{2}{*}{$\begin{array}{c}\text { \% Change in } \\
\text { Price }\end{array}$} \\
\hline & $\underline{R O W}$ & $\underline{U S A}$ & $\underline{R O W}$ & $\underline{\text { USA-Jenkins (2015) }}$ & \\
\hline & \multicolumn{5}{|c|}{ Gasoline } \\
\hline 1 & -0.03 & -0.02 & 0.11 & -0.17 & 4.38 \\
\hline 2 & -0.08 & -0.05 & 0.21 & -0.34 & 8.16 \\
\hline 3 & -0.10 & -0.06 & 0.18 & -0.34 & 5.07 \\
\hline \multirow[t]{2}{*}{4} & -0.12 & -0.06 & 0.16 & -0.34 & 4.29 \\
\hline & \multicolumn{5}{|c|}{ Distillate Fuel or Gas Oil } \\
\hline 1 & 0.00 & 0.00 & 0.02 & -0.02 & 0.62 \\
\hline 2 & -0.01 & 0.00 & 0.03 & -0.04 & 1.41 \\
\hline 3 & -0.01 & -0.01 & 0.03 & -0.04 & 0.94 \\
\hline \multirow[t]{2}{*}{4} & -0.01 & -0.01 & 0.03 & -0.04 & 0.86 \\
\hline & \multicolumn{5}{|c|}{ Aviation Fuels } \\
\hline 1 & -0.12 & -0.14 & 0.43 & -0.69 & 63.46 \\
\hline 2 & -0.29 & -0.34 & 0.74 & -1.37 & 117.95 \\
\hline 3 & -0.38 & -0.41 & 0.59 & -1.37 & 75.81 \\
\hline \multirow[t]{2}{*}{4} & -0.42 & -0.43 & 0.53 & -1.37 & 67.24 \\
\hline & \multicolumn{5}{|c|}{ Residual Fuel Oil } \\
\hline 1 & 1.51 & 0.27 & 0.19 & 1.59 & -76.14 \\
\hline 2 & 2.89 & 0.62 & 0.33 & 3.18 & -87.91 \\
\hline 3 & 2.67 & 0.77 & 0.27 & 3.18 & -59.72 \\
\hline \multirow[t]{2}{*}{4} & 2.54 & 0.88 & 0.24 & 3.18 & -56.43 \\
\hline & \multicolumn{5}{|c|}{ Other Petroleum Products } \\
\hline 1 & -0.08 & -0.03 & 0.12 & -0.23 & 12.48 \\
\hline 2 & -0.19 & -0.06 & 0.21 & -0.46 & 14.75 \\
\hline 3 & -0.21 & -0.07 & 0.17 & -0.46 & 11.74 \\
\hline \multirow[t]{2}{*}{4} & -0.23 & -0.08 & 0.15 & -0.46 & 10.78 \\
\hline & \multicolumn{5}{|c|}{ Liquid Petroleum Gases } \\
\hline 1 & -0.01 & -0.03 & 0.06 & -0.10 & 11.36 \\
\hline 2 & -0.02 & -0.06 & 0.12 & -0.20 & 16.67 \\
\hline 3 & -0.02 & -0.07 & 0.10 & -0.20 & 15.41 \\
\hline \multirow[t]{2}{*}{4} & -0.03 & -0.08 & 0.09 & -0.20 & 15.04 \\
\hline & \multicolumn{5}{|c|}{ Petroleum Coke } \\
\hline 1 & -0.10 & -0.21 & 0.01 & -0.32 & 305.79 \\
\hline 2 & -0.20 & -0.41 & 0.02 & -0.64 & 275.50 \\
\hline 3 & -0.21 & -0.41 & 0.02 & -0.64 & 165.11 \\
\hline 4 & -0.21 & -0.41 & 0.01 & -0.64 & 184.73 \\
\hline
\end{tabular}


higher costs. While petroleum coke producers overseas increase production, the gain is very small, so that only sharply lower consumption here and abroad can balance the market.

Overall, shutting down petroleum coke capacity would change the composition of US output of refined petroleum production. Output of residual fuel oil would increase while production of petroleum coke and, most importantly, production of light products, such as aviation fuels, would decrease. While higher production overseas and price-induced conservation limits some of the resulting upward pressure on prices, the net effect is a sharp increase in prices for aviation fuels and double-digit percentage price increases for other petroleum products and liquid petroleum gases. Gasoline prices would increase from 4 to 8 percent while distillate fuel oil prices would increase around 1 percent. Petroleum coke prices more than triple and world prices for residual fuel oil would plummet.

Changes in the trade balances and consumer expenditures are displayed in Figure 6. After the four-year adjustment period, the US trade balance in petroleum products declines $\$ 27.9$ billion from a $\$ 17.8$ billion surplus under the baseline scenario to a $\$ 10.1$ deficit billion annual deficit after a shutdown of petroleum coke production. Expenditures on petroleum products in the US increase by over $\$ 60$ billion during the second year and remain more than $\$ 40$ billion higher after shutting down US petroleum coke production. The increases in expenditures for the rest of the world are considerably larger, ranging from $\$ 9.9$ to over $\$ 146$ billion.

\section{Conclusion}

Environmental concerns have led to proposals to restrict the transportation of

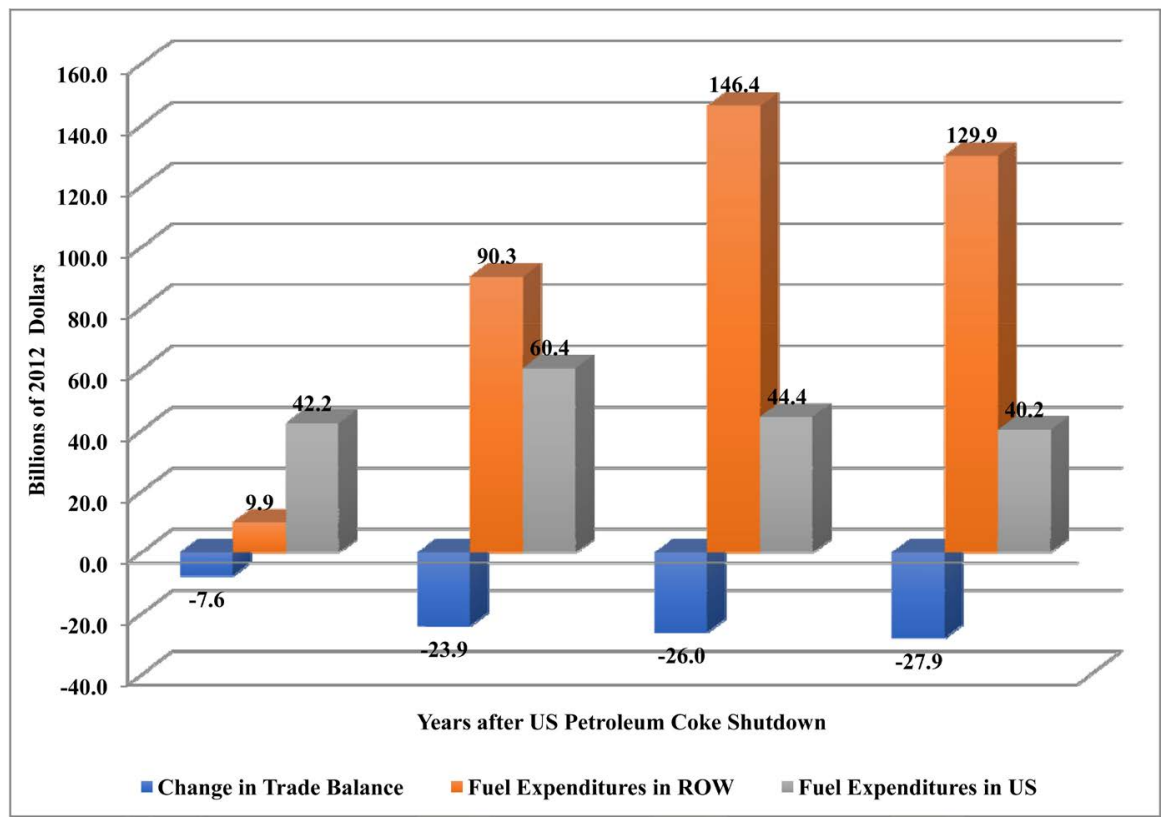

Figure 6. Changes in trade balance and consumer expenditures. 
petroleum coke. This paper estimates the market impacts of these proposed bans and, in effect, determines the value of petroleum coke to refined petroleum product markets. Shutting down US petroleum coke capacity would disrupt refined petroleum products markets, lowering prices for residual fuel oil and increasing prices for aviation fuels, petroleum coke, other petroleum products, liquid petroleum gases, and gasoline. Shutting down petroleum coke production in the US would hurt the trade balance, over a four-year period the losses could mount to over $\$ 85$ billion. Without petroleum coke, consumers would pay $\$ 187.2$ and $\$ 376.5$ billion more in the US and the rest of the world respectively for refined petroleum products.

\section{Claim}

This paper is sponsored under a research contract between the Office of Sponsored Programs at the University of Wyoming and Koch Carbon LLC. The analysis, findings, and conclusions expressed in this paper are solely those of the author and are not necessarily those of the University of Wyoming or Koch Carbon LLC. The author accepts all responsibility for any errors or omissions.

\section{Conflicts of Interest}

The author declares no conflicts of interest regarding the publication of this paper.

\section{References}

[1] Leffler, W.L. (2000) Petroleum Refining in Nontechnical Language. Penn Well, Tulsa.

[2] David, M. (2014) Push Continues for Greater Scrutiny on Petroleum Coke in Detroit and Beyond. Michigan Live.

[3] Durbin, R. (2015) Regulation of Petroleum Coke as a Hazardous Waste. US Senate. https://environmentalnewsstand.com/sites/insideepa.com/files/documents/jan2015/ epa2015_0108b.pdf

[4] Natural Resources Defense Council (2013) Petcoke Problems: Tar Sands Waste Piling Up on Chicago's Southeast Side. Press Release.

http://www.nrdc.org/media/2013/131018.asp

[5] Oil Change International (2013) Petroleum Coke: The Coal Hiding in the Tar Sands.

http://priceofoil.org/2013/01/17/petroleum-coke-the-coal-hiding-in-the-tar-sands/

[6] Jordon, L. (2014) Southeast Coalition to Ban Pet Coke Response to Request for Public Comment.

http://www.cityofchicago.org/content/dam/city/depts/cdph/environmental_health_ and_food/PetCoke_Public_Comments/Southeast_Side_Coalition_to_Ban_Petcoke_ Extension_Request_1-31-14.pdf

[7] John, U. (2014) San Francisco Considers Banning Exports of Coal and Petcoke. Grist.

http://grist.org/news/san-francisco-considers-banning-exports-of-coal-and-petcoke/

[8] International Energy Agency (2014) World Energy Statistics. http://www.oecd-ilibrary.org/energy/data/iea-world-energy-statistics-and-balances _ 
$\underline{\text { enestats-data-en }}$

[9] US Energy Information Administration (2014) Refinery \& Blender Net Production. https://www.eia.gov/dnav/pet/pet_pnp_refp_dc_nus_mbblpd_a.htm

[10] US Energy Information Administration (2014) Downstream Processing of Fresh Feed Input. https://www.eia.gov/dnav/pet/pet_pnp_dwns_dc_nus_mbblpd_m.htm

[11] Cuddington, J.T. and Dagher, L. (2014) Estimating Short and Long-Run Demand Elasticities: A Primer with Energy Sector Applications. The Energy Journal, 36, 185-203.

[12] US Energy Information Administration (2014) State Energy Data System. http://www.eia.gov/state/seds/seds-data-complete.cfm?sid=US

[13] International Energy Agency (2014) Energy Prices and Taxes. http://www.iea.org/statistics/topics/pricesandtaxes/

[14] World Bank (2014) World Bank National Accounts Data. http://data.worldbank.org/indicator/NY.GDP.MKTP.CD

[15] Lidderdale, T. (1998) Environmental Regulations and Changes in Petroleum Refining Operations. http://www.eia.gov/forecasts/steo/special/pdf/enviro.pdf

[16] Consultancy, J. (2012) EU Pathway Study: Life Cycle Assessment of Crude Oils in a European Context. Alberta Petroleum Marketing Commission. https://www.energy.alberta.ca/Oil/Documents/OSPathwayAppendix1WorkScope.pdf

[17] Jenkins, J.H. (2015) A World without Cokers: Or at Least the US. 14th Annual Petcoke Conference, Orlando, 13-14 March 2015. 
Appendix A: Mean Squared Error Decomposition

\begin{tabular}{|c|c|c|c|c|c|c|c|c|}
\hline & \multicolumn{5}{|c|}{ MSE Decomposition } & \multicolumn{3}{|c|}{ MSE Decomposition } \\
\hline & $M S E$ & Bias & Reg. & Resid. & $M S E$ & Bias & Reg. & Resid \\
\hline & \multicolumn{4}{|c|}{ Gasoline } & \multicolumn{4}{|c|}{ Liquid Petroleum Gases } \\
\hline US Demand & 0.01 & 0.20 & 0.02 & 0.78 & 0.02 & 0.01 & 0.00 & 0.99 \\
\hline ROW Demand & 0.02 & 0.41 & 0.08 & 0.51 & 0.02 & 0.20 & 0.03 & 0.77 \\
\hline US Supply & 0.01 & 0.08 & 0.00 & 0.92 & 0.03 & 0.09 & 0.01 & 0.91 \\
\hline ROW Supply & 0.04 & 0.52 & 0.26 & 0.22 & 0.10 & 0.25 & 0.62 & 0.14 \\
\hline \multirow[t]{2}{*}{ Price } & 0.18 & 0.54 & 0.22 & 0.24 & 0.31 & 0.45 & 0.15 & 0.41 \\
\hline & \multicolumn{4}{|c|}{ Distillate } & \multicolumn{4}{|c|}{ Other Products } \\
\hline US Demand & 0.01 & 0.00 & 0.02 & 0.98 & 0.02 & 0.08 & 0.01 & 0.91 \\
\hline ROW Demand & 0.01 & 0.00 & 0.00 & 1.00 & 0.04 & 0.06 & 0.03 & 0.91 \\
\hline US Supply & 0.02 & 0.00 & 0.00 & 1.00 & 0.04 & 0.10 & 0.05 & 0.85 \\
\hline ROW Supply & 0.02 & 0.00 & 0.07 & 0.93 & 0.03 & 0.20 & 0.07 & 0.74 \\
\hline \multirow[t]{2}{*}{ Price } & 0.13 & 0.04 & 0.17 & 0.79 & 0.26 & 0.20 & 0.65 & 0.16 \\
\hline & \multicolumn{4}{|c|}{ Aviation Fuels } & \multicolumn{4}{|c|}{ Petroleum Coke } \\
\hline US Demand & 0.02 & 0.00 & 0.01 & 0.99 & 0.03 & 0.03 & 0.02 & 0.95 \\
\hline ROW Demand & 0.02 & 0.00 & 0.05 & 0.95 & 0.07 & 0.08 & 0.16 & 0.76 \\
\hline US Supply & 0.03 & 0.01 & 0.05 & 0.94 & 0.05 & 0.00 & 0.20 & 0.79 \\
\hline ROW Supply & 0.02 & 0.00 & 0.04 & 0.95 & 0.02 & 0.04 & 0.01 & 0.96 \\
\hline Price & 0.14 & 0.08 & 0.09 & 0.83 & 0.26 & 0.00 & 0.66 & 0.34 \\
\hline \multicolumn{9}{|c|}{ Residual Fuel Oil } \\
\hline US Demand & 0.02 & 0.26 & 0.21 & 0.53 & & & & \\
\hline ROW Demand & 0.02 & 0.24 & 0.00 & 0.76 & & & & \\
\hline US Supply & 0.09 & 0.01 & 0.17 & 0.83 & & & & \\
\hline ROW Supply & 0.05 & 0.00 & 0.00 & 1.00 & & & & \\
\hline Price & 0.25 & 0.40 & 0.26 & 0.34 & & & & \\
\hline
\end{tabular}

